\title{
Enhanced Multi-Faceted Teaching Methods: Phase III- Adjunct Faculty
}

Dennis L. Payette, (Email: payette@adelphi.edu), Adelphi University

Daniel Verreault, (Email: dverreault@ut.edu), University of Tampa

\begin{abstract}
This paper is the third in a series conducting research on teaching methods and technologies at Adelphi University School of Business. First, (Phase I) the methods and instrument were developed. Second, data from full time faculty was collected and analyzed (Phase II). Third, (Phase III) data has been collected concerning the extent of use and perceived value of use of various technologies from part-time faculty which we analyzed and compared to the results from the full-time faculty. The issues of part-time faculty attitudes toward technology and their use of technology to support teaching are important to the academic mission and emphasized under AACSB standards for business schools. In the environment studied, part-time faculty perceptions of the levels of use and their opinions of the value of use of various technologies were virtually indistinguishable from those of full-time faculty. Neither departmental affiliation nor teaching experience was a significant factor in explaining the responses of part-time faculty. The authors conclude that the part-time faculty cadre studied is highly socialized and consistent with the full-time faculty on the dimensions studied.
\end{abstract}

\section{INTRODUCTION}

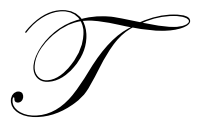

his paper is the third in a series of research projects focusing on various teaching technologies and methodologies. This stream of pedagogical research in a university business school (Adelphi University) was designed to gather objective and factual data on not only what technologies (what were classifieds as "hard" and "soft" technologies) but what teaching methods were being employed on the undergraduate and master's degree level. Further, the research has gathered information on the level of use and how faculty value the various technologies and methods they may be employing in their structural activities.

The first paper (Payette 2004) developed an instrument to gather data on traditional teaching methods and other more recently developed technologies and methods. This instrument was pre-tested and refined for presentation at the TLC Conference in January 2003. In addition this paper provided definitions and descriptions of the various elements in the survey instrument. Next, the instrument was administered to a group of full time business faculty and the results were statistically analyzed and presented at the TLC Conference in January 2004. This research established an approach and data base that could be used for future comparisons and analysis (Payette and Verreault 2005). This paper is the result of surveying the part-time faculty in the same institution to accomplish two objectives. First, this will be the first pedagogical research focusing on adjunct faculty in the School of Business at Adelphi University and second, it presents a comparative analysis between a group of full-time and part-time faculty with respect to the value and level of use of various teaching methods and technologies.

The authors believe that this analysis will provide a comprehensive pedagogical analysis of the entire Business faculty at Adelphi University to assist in the continuous improvement initiatives as part of their candidacy for AACSB accreditation. The research also adds to our understanding of factors affecting part-time faculty. The growth of the part-time faculty component is of importance to all constituents of higher education whether inside or outside the business school environment. 


\section{DEFINITIONS}

As the review of the literature commenced on adjunct faculty it became clear that there is a wide range of terms applied to what this paper refers to as "part-time faculty". For the purpose and intent of this research we define "part-time faculty" as follows:

any faculty member who is not appointed as a full-time tenure track instructor; any faculty member who does not have tenure and teaches less than the contractually mandated course load assigned to full-time faculty, and adjunct faculties who are assigned on a "course available" basis.

The literature reveals that definitions vary by institution and by collective bargaining agreements. Other terms applied to adjunct faculty include:

- $\quad$ Adjunct faculty - used interchangeably with part-time faculty

- $\quad$ Contingent Academic Labor and

- $\quad$ Contract Part-time faculty (Ehrenberg, 2005)

- $\quad$ Supporting faculty member (AACSB definition)

Perhaps the most comprehensive definition of adjunct faculty developed recently is from The Association to Advance Collegiate Schools of Business (hereinafter referred to as AACSB). It states that:

A supporting faculty member does not, as a rule, participate in the intellectual or operational life of the school beyond the direct performance of teaching responsibilities. Usually, a supporting faculty member does not have deliberative or involvement rights on faculty issues, have membership on faulty committees, nor is the individual assigned responsibilities beyond direct teaching functions (i.e., classroom and office hours). A supporting faculty member's appointment is normally exclusively teaching responsibilities and is normal ad hoc appointment, for one term or one academic year at a time without the expectation of continuation. (AACSB 2005, $p$ 36-7)

This definition is included to provide an accurate comparison of the two "types" of faculty. Full time faculty are defined by AACSB as "participating faculty". The definition is reproduced to demonstrate to level of complexity and degree of specificity now being applied by AACSB in its accreditation process. This definition of full-time is as follows:

A participating faculty member actively engages in the activities of the school in matters beyond direct teaching responsibilities. Such matters might include policy decisions, educational directions, advising, research, and service commitments. The faculty member may participate in the governance of the school, and be eligible to serve as a member on appropriate committees that engage in academic policymaking and/or other decisions. The individual may participate in a variety of non-class activities such as directing extracurricular activity, providing academic and career advising, and representing the school on institutional committees. The school considers the faculty member to be a long-term member of the faculty regardless of whether or not the appointment is of a full-time or adjunct nature, regardless of whether or not the position with the school is considered the faculty member's principal employment, and regardless of whether or not the school has tenure policies. The individual may be eligible for, and participate in, faculty development activities and take non-teaching assignments for such activities as advising as appropriate to the faculty role as defined at the school. (AACSB 2005, p.36)

It is too soon to determine if the AACSB definitions of full-time and adjunct faculty status will become part of the generally accepted terminology in higher education. It will, as part of the accreditation regulations, be used by any candidate for accreditation and from all accredited schools of business who must now "embark on a continuous process of accreditation maintenance." (AACSB Eligibility Procedures, 2005, p.2.). Contingent or Contract academic labor only recently used by Ronald Ehrenberg in a paper delivered at a TIAA-CREF Institute Conference in New York (November 3-5, 2005) is yet another definition which include "part-time or full-time Non-tenure track position." Ehrenberg cited Aderson (2002) Baldwin and Chronister (2001), Conley, Lesley and Zimblor (2002), Ehrenberg and Zhang (2005a). 
These definitions point towards an expansion of who is classified as part-time, which could include nontenured full-time lines and part-time which would include only faculty with less than a full-time work load however work is defined at each institution. The concept of "Supporting Faculty Members" developed by AACSB and promulgated as part of Eligibility Procedures and Accreditation Standards for Business Accreditation (2005) also eliminates any distinction between full and part-time faculty but uses the term of "supporting faculty members" for faculty hired exclusively for teaching on a temporary basis and "without the expectation of continuation" (AACSB regulation, 2005, p.37).

\section{PREVIOUS RESEARCH}

Since the landmark research project in 1998, by the National Center for Education Statistics on "A Profile of Part-time Faculty: Fall 1998, it appears that the research literature is steadily growing (http://NCES.ed.gov/ pubsearch/) in scope and breadth. The NCES study was able to provide a comprehensive data base upon which researchers could draw upon to conduct additional studies. In 1999, The National Study of Postsecondary faculty (NSOPF: 99) updated two previous NSOPF studies done in 1988 and 1993, "to fill the information gap about this important segment in post secondary education (p.vii). Until this research was conducted, relatively little was known about the characteristics of part-time faculty compared to full time faculty on a national basis. Some of the earlier research and monographs will be discussed later in this section.

When the literature, reports, books, and other publications are examined several trends with respect to adjunct faculty emerge. The National Center for Education Statistics reported the following on the apparent shift in the percentages of full-time and part-time faculty:

From 1976 to 1991, the number of full-time staff increased by 34 percent; however, since 1991, full-time staff has decreased by 1 percent. The number of part-time staff, on the other hand, has experienced continuous growth since 1976, rising 64 percent from 1976 to 1995 and 18 percent from 1991 to 1995 (NCES-98-228).

The NCES paper (No. 2002-08) published an analysis of information collected in 1998, on part-time faculty reported that 57 percent of all post-secondary faculty were full-time and 43 percent were part-time. While the overall trend towards significant increases in part-time instructional staff is in fact happening it should be noted that the NCES data does include non teaching instructional staff in their data. The latest NCES report (NCES 2005-172) states that in 2003 (data reported in 2005):

Among faculty and instructional staff in all institution types, 56 percent were employed full-time and 44 percent were employed part- time in Fall 2003 (Table 1).

The information, while documenting the increase in levels of part-time faculty, does not address issues pertaining to the impact that part-time faculty may have on instructional quality and outcomes. Another article by Conley and Leslie (2002) sponsored by NCES suggests that:

What is perhaps surprising to some, however, is that we have very little historical information about the characteristics of part-time faculty overall and that we have even less information about the similarities and differences among part-time faculty members and between part-time and full-time faculty in general (NCES 2002-163) as reported in Education Statistics Quarterly Vol. 4, Issue 2.

The present study was originally designed to begin to address precisely that lack of information with respect to how a particular school of business faculty uses various instructional methods and technologies and how they value their uses.

In attempting to gather more information on the uses of adjuncts other sources such as Grappa's monograph (1984), The National Education Association's handbook, Part-time and Temporary Faculty (1989), and Bower and Shuster (1986, P.60-66) were examined. All point towards the increase in the number of adjuncts but few sources focus on the in-class teaching process of adjuncts. One exception is Bianco-Mathis and Chalofsky (1996, p.55) in The 
Adjunct Faculty Handbook which does have several chapters on the pedagogical process. Conely and Leslie (NCES 2002-163) conclude in their paper that, the increases in the numbers of adjunct faculty may have "Negative impacts . . . on the quality of the academy" (p.8). The operative word in the previous statement is, of course, "may" have negative impacts. Given the increased utilization of adjuncts it is clear that additional research on part-time teaching is necessary.

It is accurate to say that more resources have been developed recently to assist adjuncts in their teaching roles. For example, Lyons' Adjunct Professor's Guide to Success (1998), Grieve and Worden's Handbook IIAdvanced Teaching Strategies for Adjunct Faculty (2000), and the Adjunct Faculty Handbook by Bianco-Mathis and Chalofsky (1996), are among the resources now available for use by adjuncts and departments providing support for improved teaching by adjuncts.

Interestingly, the internet is also beginning to play an important role in creating an online resources designed specifically for adjuncts. A site for finding adjunct positions and articles concerning adjuncts can be found on http://www.adjunct.pia.com. Another site is http://www.adjunctnation.com, a comprehensive site with an online magazine, a book store, archived information, jobs, message boards, events, financial issues, teaching tools and surveys. Perhaps the most comprehensive online adjunct teaching support system is http://www.4faculty.org, a system "originally designed to provide a cost-effective and convenient approach to orientation and professional development of adjunct faculty" (Knight 2004). The site is sponsored by the California Community College System which faces the need to train " 5000 new adjunct positions in the next 5 years state-wide" (page 2 of the website). The primary purpose is to "promote excellent instruction" by adjunct faculty. The site, in its latest model, 4 faculty/version2 has twenty training modules including "Approaches to Teaching, Technology in the Classroom," and eighteen other modules. The site also includes recommendations on other sources for each topic module selected by 4 faculty.org editors.

While increased academic support for adjuncts is developing, other research suggests problems associated with heavier reliance on adjunct faculty members. Sonner (2002), in reporting on her research on grade inflation says:

This research indicates that differences exist between the grades given by adjuncts and grades given by full-time faculty. Even after controlling for the impact of other factors that could explain the differences, grades tend to be higher in classes taught by adjunct

faculty (Sonner 2002, p.5).

Schroeder, in an article in The Chronicle of Higher Education (Oct. 28, 2005) Special Section on Community Colleges, says that new research about to be published indicates graduation rates increase when more full-time faculty are provided to students. Fulton (2000) in an article on "The Plight of Part-timers in Higher Education" catalogues what he perceives as the major problems associated with part-time faculty and he distinguishes between "part-time" and "adjunct" faculty, the latter being full-time faculty who are non-tenure track faculty. Low pay, no benefits, no development assistance, no or few offices, and no job security are among the common complaints associated with being an adjunct faculty member. He concludes that:

Both the colleges and the part-time faculty have created a thoroughly unethical and unhealthy atmosphere by pretending that either that one can live on a collection of part-timer's stipends or that no one is really trying to do so-thus we needn't address the issue (October 28, 2005, p.B27).

The evidence appears to be pointing towards significant controversy regarding the overall academic impact of heavy reliance on adjunct faculty. Wickun and Stanley in The Montana Professor Academic Journal (Win 2000) provide a comprehensive discussion of the issues including academics, financial, and professional concerns for adjuncts in the higher education overall. They conclude that adjuncts are important for instruction in that $40 \%$ of credit hours taken by students are from adjuncts (which coincide with the NCES research reported earlier in this paper), and that adjuncts will be necessary to balance institutional budgets, that recognition of the need do improve adjunct instruction is being recognized, and a proactive approach should be taken to enhance instruction. They further recommended that: 
Additional studies should be conducted on the successful employment of adjunct faculty and the implications on the quality of instruction in higher education ( $p 5$ ).

They also suggest that internal workshops between administrators and department chairs on ways to improve the use of adjunct faculty should be held.

One of the most interesting and thought provoking articles on adjunct faculty was delivered at an invitational conference on the "New Balancing Act in the Business of Higher Education" sponsored by The TIAA-CREF Institute, Nov. 3-4, 2005, by Ronald G. Ehrenberg. He wrote on "The changing Nature of the Faculty and Faculty Employment Practices (Revised Draft, November 6, 2005). Ehrenberg cites the dramatic increase in part-time and full-time nontenure track faculty since 1975, and he uses the terms, "contingent or contract" faculty in place of part-time and nontenure track full-time faculty. Ehrenberg reinforces the literature previously reported in this paper that retention and graduation rates are adversely affected by over reliance on part-time faculty. It was interesting to note that among the five major faculty issues raised in this paper the first and longest section was devoted to the growth in "contingent faculty."

President John E. Sexton of NYU who was a member of the panel along with Professor Ehrenberg disputed some of the assertions that part-time faculty could negatively affect the quality of education. Sexton pointed to "New York's deep pool of talent" to provide highly qualified part-time faculty (Chronicle of Higher Education, 11/18/05, p.A.13). In a table (1) included in Ehrenberg's paper, six large private universities and the percentage of faculty by category were portrayed. NYU had the largest percentage of part-time non-tenure track faculty at $62 \%$ and Cornell (Ehrenberg's home institution) had only $6 \%$ of its faculty in that category.

Table 1

Numbers And Percentages Of Faculty In Different Categories At Selected Private Universities In 2003-2004

\begin{tabular}{|c|c|c|c|c|}
\hline Institution & Total faculty Size & $\begin{array}{c}\text { Tenured and Tenure } \\
\text { Track (percentage) }\end{array}$ & $\begin{array}{c}\text { Full-time Non Tenure } \\
\text { Track (percentage) }\end{array}$ & $\begin{array}{c}\text { Part-Time Non } \\
\text { Tenure Track } \\
\text { (percentage) }\end{array}$ \\
\hline Boston College & 1089 & $548(50 \%)$ & $131(12 \%)$ & $410(38 \%)$ \\
\hline Brown & 902 & $468(52 \%)$ & $285(32 \%)$ & $149(17 \%)$ \\
\hline Cornell & 1940 & $1477(76 \%)$ & $348(18 \%)$ & $115(6 \%)$ \\
\hline NYU & 5083 & $1292(25 \%)$ & $630(12 \%)$ & $3162(62 \%)$ \\
\hline Rochester & 591 & $465(79 \%)$ & $100(17 \%)$ & $26(4 \%)$ \\
\hline Tufts & 1036 & $359(35 \%)$ & $275(27 \%)$ & $402(39 \%)$ \\
\hline
\end{tabular}

Source: report from the ad hoc Committee on Contract Faculty to the Provost and the Faculty Senate, Brandeis University (March 17, 2005), appendix table A-2 (available on the web at www.brandeis.edu/departments/provost/contract_faculty_comm.html). The data come from the 2003 IPEDs EAP Survey (available at http://nces.ed.gov/ipeds). The data are as reported by the institutions. Employees who do not have faculty status are excluded, as are graduate assistants. This chart is reproduced from the unpublished paper by Ehrenberg, "The Changing Nature of Faculty Employment Practices" (2005).

What the literature reveals is no disagreement over the significant increase in the employment of adjunct faculty. What is disputed is the effect that this trend has upon the quality of education and upon questions of student persistence towards graduation when they are in schools with significant utilization of adjunct faculty. There seems to be nothing in the immediate future that would lead one to conclude that his trend of increased use of part-time faculty will abate. Therefore, many institutions and systems like California's community colleges, www.4faculty.org are developing better means of professional development for part-time faculty. The thrust of this paper is to develop accurate information on how both full and part-time faculty compare in their level of use of various teaching methods and technologies and their evaluation of these methods.

\section{THE AACSB INITIATIVES: WHO IS FULL-TIME AND WHO IS PART-TIME?}

Given the fact that the subject of this paper and its two antecedent papers (Payette, 2004 and Payette and Verreault, 2005) focuses on teaching methods and technologies in a school of business, it is appropriate to examine in 
greater detail the development by AACSB in 2005 of the conceptualization of what constitutes full and part-time service as a faculty member. AACSB, more formally known as AACSB - International now has 1000 members from 70 countries representing "the combined influence of its member universities, including more than 30,000 faculty members and 700,000 students majoring in business." (http://AACSB.edu/members/) Membership in the association does not mean or confer accreditation. Accreditation is only conferred upon members who have demonstrated acceptance and achievement of the standards set by AACSB. There are currently (December 2005) 515 accredited institutions, 80 of which are non U.S. institutions.

By any standard, AACSB wields significant influence on the development of its member institution and by virtue of granting accreditation determines precisely the standards school of business must achieve to receive and maintain accreditation. As AACSB memberships and accreditation has grown outside the US, new standards (AACSB STANDARDS, Jan 2005) were developed to accommodate the differences that exist with respect to faculty international hiring practices in general and in schools of business in particular. That is why the definitions of "participating faculty" and "supporting faculty" (AACSB Standards, p. 36, 37) were included in their entirety in the Definitions section of this paper.

It is not at all unlikely that these definitions may become quite influential beyond accredited business schools as there are clearly, as the review of the literature reveals considerable differences in what is meant by full-time and part-time faculty. This is particularly true when foreign schools of business apply practices that vary broadly from most U.S. standards. AACSB's definitions mean engagement in faculty "curriculum design, course development, course delivery, and assessment of learning" (AACSB standards, 2005, p. 35). By implication, any or all of their criteria could be met by either full or part time faculty. When one examines the significant increase in the use of parttime faculty that are organized in unions or professional associations in order to have greater influence on policies that determine their academic and financial destinies. Individual institutions and schools of business might also will to enhance the role of part-time faculty whose ranks, if recent trends continue, wish represent an ever increasing segment of teaching duties.

A final comment on the review of the literature: It is clear from well documented research, primarily the NCES studies and others, that under most circumstances part-time faculty are being used to offset budget issues and avoid expensive addition of full-time faculty, and that some research suggests higher graduation rates occur with larger proportions of full-time faculty. This paper extends the research on part-time faculty by examining the patterns of use of various teaching technologies by part-time faculty and comparing part time faculty usage to full-time faculty usage.

\section{SAMPLE DESCRIPTION}

We administered the questionnaire to 29 adjunct faculty members and received 24 responses for an 83 percent response rate. For the sake of statistical comparison the same data that was collected from the full time faculty was also collected from adjunct faculty. We collected data on three factors "Teaching Experience" at four levels "Teaching Fields" for the five departments; and "Tenure" status (full-time faculty survey only). Technologies/Methods investigated were classified under three categories; "Soft" technologies, "Hard" technologies, and "Class Room" type. "Soft" technologies consisted of Essay Exams, Attendance, Research Projects, Guest Lecturers, and student teams. Hard Technologies consisted of Overhead Projectors, Email, Streaming Video, Internet Access, Blackboard, PowerPoint, Publisher Aids, Laser Pointer, Laptop computers, Elmo Projector and Infocus Projector. Classrooms were divided into Smart Classrooms, Hybrid Classrooms and Standard Classrooms.

Responses were numerical at five levels on both the level of use and the value of use each Technology/Method at both the graduate and undergraduate levels. The responses numbered " 5 " for both the Level of Use scale (response 5 is "Intend to use") and Value of Use scale (response five is "Have not used") did not enter into the primary analysis. The response "Intend to use" was collected as a measure of demand or sentiment for a technology or method. For primary statistical analysis, "Intend to use" responses were coded into the response "Never" which is the first scale item for analysis. The response "Have not used" was collected as a response for those not able to make an assessment of the value of a particular technology or method and was coded as missing for 
analysis. Therefore, analyzed responses were on a four point scale. See Figure 1 for the adjunct data collection instrument. Table 2 shows the adjunct survey instrument complete with demographic data and mean responses to the questions.

Figure 1

Adjunct Faculty Survey On Teaching Methods And Technologies

1. Teaching Experience: $<3$

2. Teaching Field:
Acct
4 - 7 years

Fin
$8-12$ years Mkt
$>12$

$$
\text { Mgmt }
$$

MIS/OPS

Scales:

\begin{tabular}{ll}
\multicolumn{2}{l}{ Level of Use: } \\
\hline 1. & Never \\
2. & Occasionally \\
3. & Frequently \\
4. & Always \\
5. & Intend to use
\end{tabular}

Value of Use:

1. Worthless

2. Worthwhile

3. Good

4. Very good

5. Have Not Used

Teaching Methods And Technologies With Level Of Use And Value Of Use

\begin{tabular}{|c|c|c|c|c|}
\hline \multirow{2}{*}{$\begin{array}{l}\text { Technologies/ } \\
\text { Methods }\end{array}$} & \multicolumn{2}{|c|}{ Graduate } & \multicolumn{2}{|c|}{ Undergraduate } \\
\hline & Level of Use & Value of Use & Level of Use & Value of Use \\
\hline \multicolumn{5}{|l|}{ Soft Technologies } \\
\hline \multicolumn{5}{|l|}{ Essay Examinations } \\
\hline \multicolumn{5}{|l|}{ Attendance } \\
\hline \multicolumn{5}{|l|}{ Research Projects } \\
\hline \multicolumn{5}{|l|}{ Guest Lecturers } \\
\hline \multicolumn{5}{|l|}{ Student Teams } \\
\hline \multicolumn{5}{|l|}{ Overhead Projector } \\
\hline \multirow{2}{*}{\multicolumn{5}{|c|}{ Other (specify) }} \\
\hline & & & & Hard Technologies \\
\hline \multicolumn{5}{|l|}{ Email } \\
\hline \multicolumn{5}{|l|}{ Streaming Video } \\
\hline \multicolumn{5}{|l|}{ Internet Access } \\
\hline \multicolumn{5}{|l|}{ Blackboard Program } \\
\hline \multicolumn{5}{|l|}{ PowerPoint } \\
\hline \multicolumn{5}{|l|}{ Publisher Aids, e.g. CD's, VCR, DVD's } \\
\hline \multicolumn{5}{|l|}{ Laser Pointer } \\
\hline \multicolumn{5}{|l|}{ Laptop } \\
\hline \multicolumn{5}{|l|}{ Elmo Projector } \\
\hline \multicolumn{5}{|l|}{ Infocus Projector } \\
\hline \multicolumn{5}{|l|}{ Other (Specify) } \\
\hline \multicolumn{5}{|l|}{ Class Rooms } \\
\hline \multicolumn{5}{|l|}{ Smart Classroom } \\
\hline \multicolumn{5}{|l|}{ Hybrid Classroom } \\
\hline Standard Classroom & & & & \\
\hline
\end{tabular}

\section{Research Questions}

The research questions addressed in the paper are:

1. How do full and part-time faculty compare in terms of experience and departmental concentration?

2. Which technologies or classroom types are valued most/least highly by part-time faculty?

3. Which technologies or classroom types are used most/least intensely by part-time faculty?

4. What are the differences between the results from the full-time faculty and the part-time faculty?

5. What are the effects of the factors teaching experience and teaching field, on the mean responses for each significant difference? 
Table 2

Demographics and Mean Responses

\section{Panel A: Respondents}

$\begin{array}{lllllll}\text { 1. } & \text { Teaching Experience: } & <3(\mathbf{2}) & 4-7 \text { years }(\mathbf{6}) & 8-12 \text { years }(\mathbf{1}) & >12(\mathbf{1 3}) & \\ \text { 2. } & \text { Teaching Field: } & \text { Acct }(\mathbf{4}) & \text { Fin }(\mathbf{4}) & \operatorname{Mkt}(\mathbf{2}) & \operatorname{Mgmt}(\mathbf{9}) & \text { MIS/OPS }(\mathbf{2})\end{array}$

Panel B: Mean Responses - Soft Technologies

\begin{tabular}{|c|c|c|c|c|}
\hline \multirow{2}{*}{$\begin{array}{l}\text { Technologies/ } \\
\text { Methods }\end{array}$} & \multicolumn{2}{|c|}{ Graduate } & \multicolumn{2}{|c|}{ Undergraduate } \\
\hline & Level of Use & Value of Use & Level of Use & Value of Use \\
\hline "Soft" Technologies & & & & \\
\hline Essay Examinations & $\mathbf{2 . 3 8} / 2.72$ & 2.92/3.44 & $2.60 / 2.44$ & $3.23 / 3.00$ \\
\hline Attendance & $3.62 / 2.76$ & $3.67 / 2.66$ & $3.60 / 3.33$ & $3.57 / 3.29$ \\
\hline Research Projects & $2.81 / 3.22$ & 3.29/3.69 & $2.47 / 2.63$ & $3.25 / 3.21$ \\
\hline Guest Lecturers & 1.93/1.61 & 3.10/3.14 & $1.67 / 1.56$ & $2.44 / 3.17$ \\
\hline Student Teams & $2.56 / 3.17$ & $2.64 / 3.60$ & $2.40 / 2.81$ & 3.00/3.13 \\
\hline
\end{tabular}

Panel C: Mean Responses - Hard Technologies

\begin{tabular}{|c|c|c|c|c|}
\hline \multirow{2}{*}{$\begin{array}{l}\text { Technologies/ } \\
\text { Methods }\end{array}$} & \multicolumn{2}{|c|}{ Graduate } & \multicolumn{2}{|c|}{ Undergraduate } \\
\hline & Level of Use & Value of Use & Level of Use & Value of Use \\
\hline \multicolumn{5}{|l|}{ Hard Technologies } \\
\hline Overhead Projector & $2.29 / 1.94$ & 2.53/2.87 & 1.94/2.00 & $2.75 / 2.79$ \\
\hline Email & 3.60/3.28 & 3.71/3.81 & 3.31/3.06 & 3.19/3.71 \\
\hline Streaming Video & $1.46 / 2.00$ & $3.20 / 3.40$ & $\mathbf{1 . 5 7 / 1 . 7 5}$ & $2.60 / 3.63$ \\
\hline Internet Access & $2.85 / 2.61$ & $3.80 / 3.64$ & $2.00 / 2.31$ & $3.22 / 3.64$ \\
\hline Blackboard Program & $2.46 / 2.44$ & $2.90 / 3.25$ & $2.07 / 2.31$ & $2.75 / 3.44$ \\
\hline PowerPoint & 2.87/2.89 & 3.50/3.50 & $2.47 / 2.88$ & 3.45/3.54 \\
\hline Publisher Aids, e.g. CD's, VCR, DVD's & $2.67 / 2.78$ & $3.46 / 3.38$ & $2.64 / 2.75$ & $3.18 / 3.50$ \\
\hline Laser Pointer & $\mathbf{1 . 3 3 / 1 . 3 9}$ & $\mathbf{1 . 8 8} / 2.40$ & $\mathbf{1 . 2 7 / 1 . 4 4}$ & $2.00 / 2.40$ \\
\hline Laptop & 2.21/1.83 & 3.10/3.44 & 1.71/1.71 & $2.71 / 3.50$ \\
\hline Elmo Projector & $2.35 / 1.69$ & $3.11 / 3.22$ & $1.57 / 1.69$ & $2.75 / 3.43$ \\
\hline Infocus Projector & $1.50 / 2.28$ & $2.60 / 3.55$ & $\mathbf{1 . 3 6} / 2.44$ & $2.00 / 3.44$ \\
\hline
\end{tabular}

Panel D: Mean Responses - Classroom Types

\begin{tabular}{|l|c|c|c|c|}
\hline \multirow{2}{*}{$\begin{array}{c}\text { Technologies/ } \\
\text { Methods }\end{array}$} & \multicolumn{2}{c|}{ Graduate } & \multicolumn{2}{c|}{ Undergraduate } \\
\cline { 2 - 5 } & Level of Use & Value of Use & \multicolumn{4}{c|}{ Level of Use } & Value of Use \\
\hline Class Rooms & $\mathbf{3 . 2 0} / 3.11$ & $\mathbf{3 . 8 6} / 3.65$ & $\mathbf{2 . 4 6 / 2 . 9 4}$ & $\mathbf{3 . 0 9} / 3.71$ \\
\hline Smart Classroom & $\mathbf{2 . 3 3 / 1 . 7 2}$ & $\mathbf{3 . 3 3} / 3.44$ & $\mathbf{2 . 0 8} / 1.75$ & $\mathbf{3 . 2 0} / 3.63$ \\
\hline Hybrid Classroom & $\mathbf{2 . 1 7 / 2 . 6 7}$ & $\mathbf{1 . 9 2 / 2 . 5 0}$ & $\mathbf{2 . 8 5} / 2.69$ & $\mathbf{2 . 6 7 / 2 . 5 0}$ \\
\hline Standard Classroom &
\end{tabular}

Note 1: The responses to the demographic data do not sum to the $\mathrm{N}$ of twenty four due to incomplete responses to those items. Note 2: Table 1 shows the adjunct mean response in bold listed first in each cell. The mean response from the prior study of full time faculty (Payette and Verreault, 2005) is also shown for comparison. The number of responses differs from $\mathrm{N}$ as a result of non responses to particular items and/or lack of part time experience at either the graduate or undergraduate level.

\section{RESULTS}

\section{Research Question 1}

Research Question 1 focused on the departmental affiliation, and teaching experience of part-time faculty. As reported in Panel A of Table 2, the sample consisted of part-time faculty affiliated as follows: nine in Management, four in Finance, four in Accounting, two in Marketing, and two in MIS/OPS. Three respondents left the field blank. The distribution is consistent with full time faculty levels except for Finance which was recruiting faculty and had a higher than normal complement of part-time faculty. In terms of teaching experience, the sample presented thirteen 
members with over twelve years experience; one member with eight to twelve years experience; 6 members with four to seven years experience; and two members with less than three years experience. Two respondents left the field blank. The overall part-time teaching cadre is relatively highly experienced and distributed, in most cases, in proportion to the full time faculty complement and the number of course offerings.

Recruitment of part time faculty is the responsibility of the department chairperson. Long standing relationships and careful recruitment are the primary methods used to socialize part-time faculty. Many of the parttime faculty members have extensive teaching experience at the school. The school has implemented a handbook for part-time faculty and is increasing contact and information flow to part-time faculty through more intense internet contact.

\section{Research Questions 2 and 3}

Research questions two and three explored the most highly and least highly valued and the most and least used technologies and classroom types. Table 2 Panel B shows the mean levels for the part-time faculty in bold and the result from the full-time faculty following. The full time faculty data were analyzed in Payette and Verreault 2005. Attendance (3.67) and research projects (3.29) scored highest in perceived graduate value of use. At the undergraduate level, attendance (3.57) and research projects (3.25) scored highest. Least valued at the graduate level were student teams (2.64) and exams (2.92). Least valued at the undergraduate level was guest lecturers (2.44). In terms of use, part-time faculty showed a high level of use of attendance at both the graduate and undergraduate levels. Attendance was the only soft technology scoring above three.

Panel $\mathrm{C}$ illustrates the mean responses for hard technologies. In terms of graduate value of use, internet access (3.80), e-mail (3.71), PowerPoint (3.50), and Publisher Aids (3.46) scored highest. At the undergraduate level, PowerPoint (3.45), e-mail (3.19), and Publisher Aids (3.18) were the most highly valued. Least valued were laser pointers (1.33), streaming video (1.46), and Infocus projectors (1.50). In terms of levels of use at the graduate level, only e-mail (3.60) scored over 3. Similarly, at the undergraduate level, e-mail (3.31) was the only hard technology scoring over 3. Again similar to the graduate scores - part-time instructors scored laser pointers (1.27), Infocus projectors (1.36), and streaming video (1.57) as the least used hard technologies at the undergraduate level.

See Table 2 panel D for the mean responses for classroom types. Part time instructors scored smart classroom as very highly valued (3.86) at the graduate level with standard classrooms least highly valued (1.92). At the undergraduate level, hybrid classrooms were valued most highly (3.20) with standard classrooms least valued (2.67). Considering levels of use at the graduate level, part-time faculty reported the highest level of use for smart classrooms (3.20) and the least for standard classrooms (2.17). At the undergraduate level, the levels of use of standard classrooms (2.85) was highest with hybrid classrooms (2.08) scoring the lowest level of use.

\section{Research Question 4}

Research question 4 requires a comparison between the mean responses for part-time faculty and the responses from full time faculty previously reported in order to examine similarities and differences between the two groups. Tables 3 through 8 report the results of the comparisons using a two-tailed independent samples t-test for equality of means. We used a two-tailed test because we had no basis a priori to specify a direction for the result and because we are interested in differences at both ends of the scale. We used SPSS v. 12 for the analysis.

Table 3 presents the results for the comparison between the means for the levels of use of soft technologies. The column labeled "Sig. (2 tailed))" shows that only the "Attendance" variables at both the graduate level (p .031) and undergraduate levels ( $p$.030) were significant with the levels of use of attendance for part-time faculty significantly higher than that for full-time faculty. All other comparisons lacked significance indicating that, except for attendance, the means of all levels of use variables at both the undergraduate and graduate levels for soft technologies could not be distinguished by faculty group in this sample. 
Table 3

Full vs. Part-Time Faculty, Soft Technologies, Level of Use, Independent Samples Test

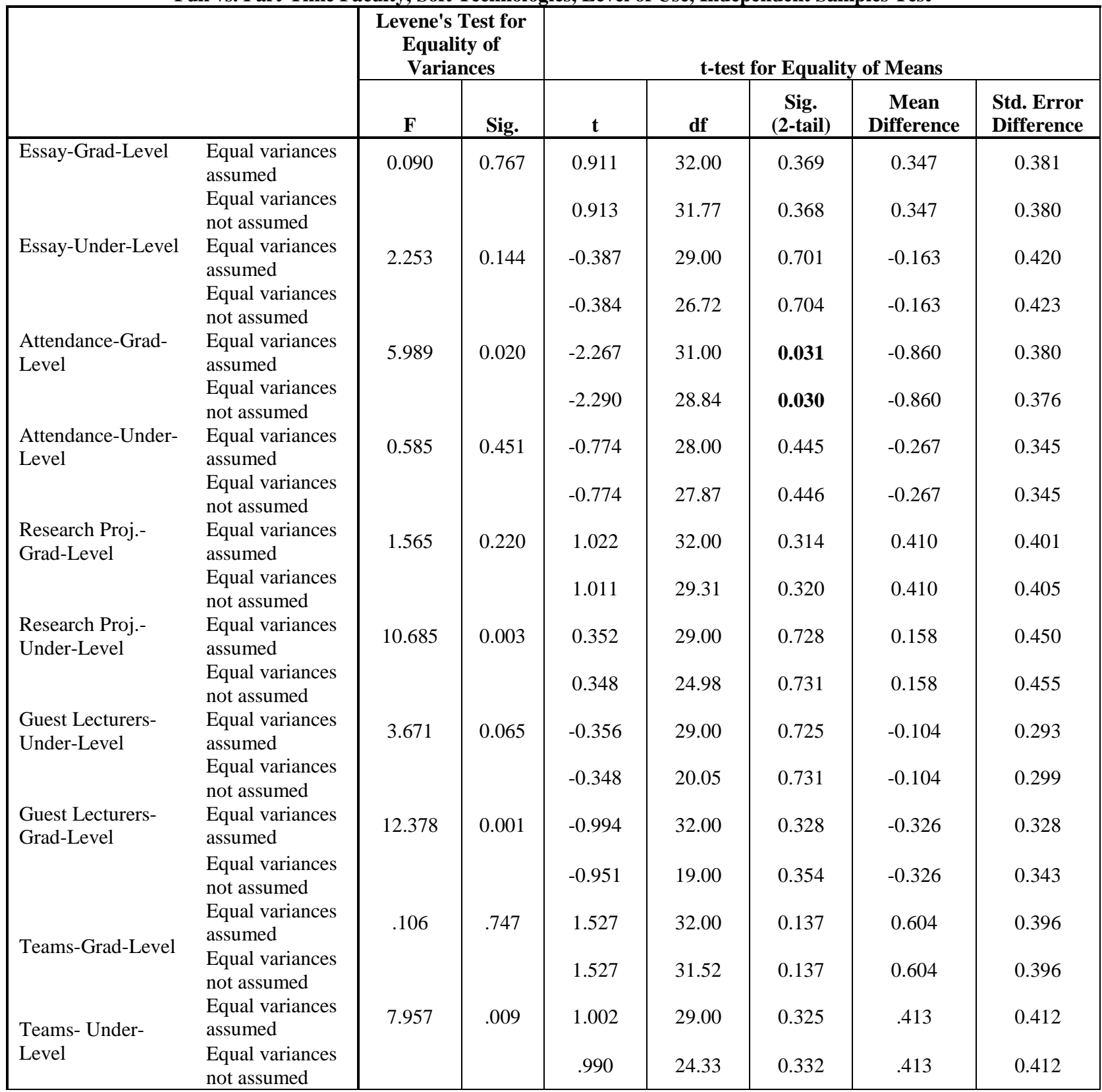

Table 4 shows the results of the equality of means test for the perceived value of use for soft technologies at both the graduate and undergraduate levels. Two items were significant. Part-time faculty viewed attendance at the graduate level as significantly higher in value (p .005) than did the full-time faculty. The second item of significance was the perceived value of teams at the graduate level. Part-time faculty judged teams to be of significantly less value ( $\mathrm{p} \mathrm{.011)} \mathrm{than} \mathrm{did} \mathrm{full-time} \mathrm{faculty} \mathrm{members} \mathrm{for} \mathrm{graduate} \mathrm{students.} \mathrm{The} \mathrm{value} \mathrm{judgments} \mathrm{of} \mathrm{part} \mathrm{and} \mathrm{full-time} \mathrm{faculty}$ concerning the other soft technologies (essays, research projects, guest lecturers, and undergraduate team work) could not be distinguished from chance differences. Many of the $\mathrm{p}$ levels were extremely high, indicating strong similarity in judgment. 
Table 4

Full vs. Part-Time Faculty, Soft Technologies - Value of Use, Independent Samples Test

\begin{tabular}{|c|c|c|c|c|c|c|c|c|}
\hline & \multicolumn{2}{|c|}{$\begin{array}{c}\text { Levene's Test for } \\
\text { Equality of Variances }\end{array}$} & \multicolumn{5}{|c|}{ t-test for Equality of Means } \\
\hline & & $\mathbf{F}$ & Sig. & $\mathbf{t}$ & df & $\begin{array}{c}\text { Sig. } \\
(2-\text { tail })\end{array}$ & $\begin{array}{c}\text { Mean } \\
\text { Difference }\end{array}$ & $\begin{array}{l}\text { Std. Error } \\
\text { Difference }\end{array}$ \\
\hline $\begin{array}{l}\text { Essay-Grad- } \\
\text { Value }\end{array}$ & $\begin{array}{l}\text { Equal variances } \\
\text { assumed } \\
\text { Equal variances } \\
\text { not assumed }\end{array}$ & 0.011 & 0.918 & $\begin{array}{l}1.857 \\
1.797\end{array}$ & $\begin{array}{l}27.00 \\
21.42\end{array}$ & $\begin{array}{l}0.074 \\
0.086\end{array}$ & $\begin{array}{l}0.514 \\
0.514\end{array}$ & $\begin{array}{l}0.277 \\
0.286\end{array}$ \\
\hline $\begin{array}{l}\text { Essay-Under- } \\
\text { Value }\end{array}$ & $\begin{array}{l}\text { Equal variances } \\
\text { assumed } \\
\text { Equal variances } \\
\text { not assumed }\end{array}$ & 1.794 & 0.192 & $\begin{array}{l}-0.634 \\
-0.627\end{array}$ & $\begin{array}{l}25.00 \\
21.67\end{array}$ & $\begin{array}{l}0.532 \\
0.538\end{array}$ & $\begin{array}{l}-0.231 \\
-0.231\end{array}$ & $\begin{array}{l}0.364 \\
0.368\end{array}$ \\
\hline $\begin{array}{l}\text { Attendance- } \\
\text { Grad-Value }\end{array}$ & $\begin{array}{l}\text { Equal variances } \\
\text { assumed } \\
\text { Equal variances } \\
\text { not assumed }\end{array}$ & 2.638 & 0.116 & $\begin{array}{l}-3.044 \\
-3.044\end{array}$ & $\begin{array}{l}28.00 \\
24.90\end{array}$ & $\begin{array}{l}0.005 \\
0.005\end{array}$ & $\begin{array}{l}-1.000 \\
-1.000\end{array}$ & $\begin{array}{l}0.329 \\
0.329\end{array}$ \\
\hline $\begin{array}{l}\text { Attendance- } \\
\text { Under-Value }\end{array}$ & $\begin{array}{l}\text { Equal variances } \\
\text { assumed } \\
\text { Equal variances } \\
\text { not assumed }\end{array}$ & 0.245 & 0.625 & $\begin{array}{l}-1.100 \\
-1.100\end{array}$ & $\begin{array}{l}26.00 \\
25.65\end{array}$ & $\begin{array}{l}0.282 \\
0.282\end{array}$ & $\begin{array}{l}-0.286 \\
-0.286\end{array}$ & $\begin{array}{l}0.260 \\
0.260\end{array}$ \\
\hline $\begin{array}{l}\text { Research Proj.- } \\
\text { Grad-Value }\end{array}$ & $\begin{array}{l}\text { Equal variances } \\
\text { assumed } \\
\text { Equal variances } \\
\text { not assumed }\end{array}$ & 5.540 & 0.026 & $\begin{array}{l}1.230 \\
1.197\end{array}$ & $\begin{array}{l}28.00 \\
22.00\end{array}$ & $\begin{array}{l}0.229 \\
0.244\end{array}$ & $\begin{array}{l}0.402 \\
0.402\end{array}$ & $\begin{array}{l}0.327 \\
0.336\end{array}$ \\
\hline $\begin{array}{l}\text { Research Proj.- } \\
\text { Under-Value }\end{array}$ & $\begin{array}{l}\text { Equal variances } \\
\text { assumed } \\
\text { Equal variances } \\
\text { not assumed }\end{array}$ & 0.386 & 0.540 & $\begin{array}{l}-0.078 \\
-0.077\end{array}$ & $\begin{array}{l}24.00 \\
21.27\end{array}$ & $\begin{array}{l}0.939 \\
0.940\end{array}$ & $\begin{array}{l}-0.036 \\
-0.036\end{array}$ & $\begin{array}{l}0.459 \\
0.466\end{array}$ \\
\hline $\begin{array}{l}\text { Guest Lecturers- } \\
\text { Grad-Value }\end{array}$ & $\begin{array}{l}\text { Equal variances } \\
\text { assumed } \\
\text { Equal variances } \\
\text { not assumed }\end{array}$ & 0.707 & 0.409 & $\begin{array}{l}0.107 \\
0.103\end{array}$ & $\begin{array}{l}22.00 \\
16.47\end{array}$ & $\begin{array}{l}0.916 \\
0.920\end{array}$ & $\begin{array}{l}0.043 \\
0.043\end{array}$ & $\begin{array}{l}0.401 \\
0.418\end{array}$ \\
\hline $\begin{array}{l}\text { Guest Lecturers- } \\
\text { Under-Value }\end{array}$ & $\begin{array}{l}\text { Equal variances } \\
\text { assumed } \\
\text { Equal variances } \\
\text { not assumed }\end{array}$ & 0.272 & 0.608 & $\begin{array}{l}1.688 \\
1.727\end{array}$ & $\begin{array}{l}19.00 \\
18.59\end{array}$ & $\begin{array}{l}0.108 \\
0.101\end{array}$ & $\begin{array}{l}0.722 \\
0.722\end{array}$ & $\begin{array}{l}0.428 \\
0.418\end{array}$ \\
\hline $\begin{array}{l}\text { Teams-Grad- } \\
\text { Value }\end{array}$ & $\begin{array}{l}\text { Equal variances } \\
\text { assumed } \\
\text { Equal variances } \\
\text { not assumed }\end{array}$ & 4.096 & 0.053 & $\begin{array}{l}2.802 \\
2.766\end{array}$ & $\begin{array}{l}27.00 \\
22.74\end{array}$ & $\begin{array}{l}0.009 \\
0.011\end{array}$ & $\begin{array}{l}0.957 \\
0.957\end{array}$ & $\begin{array}{l}0.342 \\
0.346\end{array}$ \\
\hline $\begin{array}{l}\text { Teams-Under- } \\
\text { Value }\end{array}$ & $\begin{array}{l}\text { Equal variances } \\
\text { assumed } \\
\text { Equal variances } \\
\text { not assumed }\end{array}$ & 0.173 & 0.681 & $\begin{array}{l}0.312 \\
0.304\end{array}$ & $\begin{array}{l}24.00 \\
19.28\end{array}$ & $\begin{array}{l}0.757 \\
0.765\end{array}$ & $\begin{array}{l}0.133 \\
0.133\end{array}$ & $\begin{array}{l}0.427 \\
0.439\end{array}$ \\
\hline
\end{tabular}

Table 5 illustrates the results of the tests for the level of use of hard technologies at both the undergraduate and graduate levels. The only item of significance was the level of use of Infocus projectors at the undergraduate level ( $\mathrm{p} \mathrm{.036).} \mathrm{All} \mathrm{other} \mathrm{tests} \mathrm{indicated} \mathrm{very} \mathrm{high} \mathrm{p}$ levels, thus indicating a high degree of similarity between parttime and full-time faculty on the levels of use of the various hard technologies. 
Table 5

Full vs. Part-Time Faculty, Hard Technologies - Level of Use, Independent Samples Test

\begin{tabular}{|c|c|c|c|c|c|c|c|c|}
\hline & \multicolumn{2}{|c|}{$\begin{array}{c}\text { Levene's Test for } \\
\text { Equality of } \\
\text { Variances } \\
\end{array}$} & \multicolumn{5}{|c|}{ t-test for Equality of Means } \\
\hline & & $\mathbf{F}$ & Sig. & $\mathbf{t}$ & df & $\begin{array}{c}\text { Sig. } \\
\text { (2-tail) }\end{array}$ & $\begin{array}{c}\text { Mean } \\
\text { Difference }\end{array}$ & $\begin{array}{l}\text { Std. Error } \\
\text { Difference }\end{array}$ \\
\hline $\begin{array}{l}\text { OH Proj.- } \\
\text { Grad-Level }\end{array}$ & $\begin{array}{l}\text { Equal variances } \\
\text { assumed } \\
\text { Equal variances } \\
\text { not assumed }\end{array}$ & 2.431 & 0.128 & $\begin{array}{l}-0.934 \\
-0.928\end{array}$ & $\begin{array}{l}33.00 \\
31.06\end{array}$ & $\begin{array}{l}0.357 \\
0.360\end{array}$ & $\begin{array}{l}-0.350 \\
-0.350\end{array}$ & $\begin{array}{l}0.37454 \\
0.37667\end{array}$ \\
\hline $\begin{array}{l}\text { OH Proj.- } \\
\text { Under-Level }\end{array}$ & $\begin{array}{l}\text { Equal variances } \\
\text { assumed } \\
\text { Equal variances } \\
\text { not assumed }\end{array}$ & 0.658 & 0.424 & $\begin{array}{l}0.174 \\
0.174\end{array}$ & $\begin{array}{l}30.00 \\
29.73\end{array}$ & $\begin{array}{l}0.863 \\
0.863\end{array}$ & $\begin{array}{l}0.063 \\
0.063\end{array}$ & $\begin{array}{l}0.35904 \\
0.35904\end{array}$ \\
\hline $\begin{array}{l}\text { E-Mail- } \\
\text { Grad-Level }\end{array}$ & $\begin{array}{l}\text { Equal variances } \\
\text { assumed } \\
\text { Equal variances } \\
\text { not assumed }\end{array}$ & 1.353 & 0.254 & $\begin{array}{l}-0.919 \\
-0.933\end{array}$ & $\begin{array}{l}31.00 \\
30.98\end{array}$ & $\begin{array}{l}0.365 \\
0.358\end{array}$ & $\begin{array}{l}-0.322 \\
-0.322\end{array}$ & $\begin{array}{l}0.35079 \\
0.34544\end{array}$ \\
\hline $\begin{array}{l}\text { E-Mail- } \\
\text { Under-Level }\end{array}$ & $\begin{array}{l}\text { Equal variances } \\
\text { assumed } \\
\text { Equal variances } \\
\text { not assumed }\end{array}$ & 3.792 & 0.061 & $\begin{array}{l}-0.681 \\
-0.681\end{array}$ & $\begin{array}{l}30.00 \\
27.62\end{array}$ & $\begin{array}{l}0.501 \\
0.502\end{array}$ & $\begin{array}{l}-0.250 \\
-0.250\end{array}$ & $\begin{array}{l}0.36728 \\
0.36728\end{array}$ \\
\hline $\begin{array}{l}\text { Streaming } \\
\text { Video-Grad- } \\
\text { Level }\end{array}$ & $\begin{array}{l}\text { Equal variances } \\
\text { assumed } \\
\text { Equal variances } \\
\text { not assumed }\end{array}$ & 2.392 & 0.133 & $\begin{array}{l}1.342 \\
1.450\end{array}$ & $\begin{array}{l}29.00 \\
28.30\end{array}$ & $\begin{array}{l}0.190 \\
0.158\end{array}$ & $\begin{array}{l}0.538 \\
0.538\end{array}$ & $\begin{array}{l}0.40118 \\
0.37129\end{array}$ \\
\hline $\begin{array}{l}\text { Streaming } \\
\text { Video- } \\
\text { Under-Level }\end{array}$ & $\begin{array}{l}\text { Equal variances } \\
\text { assumed } \\
\text { Equal variances } \\
\text { not assumed }\end{array}$ & 0.332 & 0.569 & $\begin{array}{l}0.502 \\
0.504\end{array}$ & $\begin{array}{l}28.00 \\
27.85\end{array}$ & $\begin{array}{l}0.619 \\
0.618\end{array}$ & $\begin{array}{l}0.179 \\
0.179\end{array}$ & $\begin{array}{l}0.35554 \\
0.35397\end{array}$ \\
\hline $\begin{array}{l}\text { Internet } \\
\text { Access- } \\
\text { Grad-Level }\end{array}$ & $\begin{array}{l}\text { Equal variances } \\
\text { assumed } \\
\text { Equal variances } \\
\text { not assumed }\end{array}$ & 0.120 & 0.732 & $\begin{array}{l}-0.570 \\
-0.561\end{array}$ & $\begin{array}{l}30.00 \\
26.24\end{array}$ & $\begin{array}{l}0.573 \\
0.579\end{array}$ & $\begin{array}{l}-0.246 \\
-0.246\end{array}$ & $\begin{array}{l}0.43152 \\
0.43831\end{array}$ \\
\hline $\begin{array}{l}\text { Internet } \\
\text { Access- } \\
\text { Under-Level }\end{array}$ & $\begin{array}{l}\text { Equal variances } \\
\text { assumed } \\
\text { Equal variances } \\
\text { not assumed }\end{array}$ & 0.378 & 0.544 & $\begin{array}{l}0.781 \\
0.786\end{array}$ & $\begin{array}{l}28.00 \\
27.94\end{array}$ & $\begin{array}{l}0.441 \\
0.438\end{array}$ & $\begin{array}{l}0.313 \\
0.313\end{array}$ & $\begin{array}{l}0.39992 \\
0.39738\end{array}$ \\
\hline $\begin{array}{l}\text { BlackBoard- } \\
\text { Grad-Level }\end{array}$ & $\begin{array}{l}\text { Equal variances } \\
\text { assumed } \\
\text { Equal variances } \\
\text { not assumed }\end{array}$ & 1.889 & 0.180 & $\begin{array}{l}-0.036 \\
-0.037\end{array}$ & $\begin{array}{l}29.00 \\
27.93\end{array}$ & $\begin{array}{l}0.972 \\
0.971\end{array}$ & $\begin{array}{l}-0.017 \\
-0.017\end{array}$ & $\begin{array}{l}0.47637 \\
0.46528\end{array}$ \\
\hline $\begin{array}{l}\text { BlackBoard- } \\
\text { Under-Level }\end{array}$ & $\begin{array}{l}\text { Equal variances } \\
\text { assumed } \\
\text { Equal variances } \\
\text { not assumed }\end{array}$ & 2.215 & 0.148 & $\begin{array}{l}0.492 \\
0.499\end{array}$ & $\begin{array}{l}27.00 \\
26.80\end{array}$ & $\begin{array}{l}0.627 \\
0.622\end{array}$ & $\begin{array}{l}0.236 \\
0.236\end{array}$ & $\begin{array}{l}0.47861 \\
0.47202\end{array}$ \\
\hline $\begin{array}{l}\text { PowerPoint- } \\
\text { Grad-Level }\end{array}$ & $\begin{array}{l}\text { Equal variances } \\
\text { assumed } \\
\text { Equal variances } \\
\text { not assumed }\end{array}$ & 0.926 & 0.343 & $\begin{array}{l}0.052 \\
0.053\end{array}$ & $\begin{array}{l}31.00 \\
30.89\end{array}$ & $\begin{array}{l}0.958 \\
0.958\end{array}$ & $\begin{array}{l}0.022 \\
0.022\end{array}$ & $\begin{array}{l}0.42360 \\
0.41859\end{array}$ \\
\hline $\begin{array}{l}\text { PowerPoint- } \\
\text { Under-Level }\end{array}$ & $\begin{array}{l}\text { Equal variances } \\
\text { assumed } \\
\text { Equal variances } \\
\text { not assumed }\end{array}$ & 0.490 & 0.490 & $\begin{array}{l}0.907 \\
0.905\end{array}$ & $\begin{array}{l}29.00 \\
28.41\end{array}$ & $\begin{array}{l}0.372 \\
0.373\end{array}$ & $\begin{array}{l}0.408 \\
0.408\end{array}$ & $\begin{array}{l}0.45009 \\
0.45127\end{array}$ \\
\hline $\begin{array}{l}\text { Publishers } \\
\text { Aids-Grad- }\end{array}$ & $\begin{array}{l}\text { Equal variances } \\
\text { assumed }\end{array}$ & 0.639 & 0.430 & 0.321 & 31.00 & 0.751 & 0.111 & 0.34646 \\
\hline
\end{tabular}




\begin{tabular}{|c|c|c|c|c|c|c|c|c|}
\hline Level & $\begin{array}{l}\text { Equal variances } \\
\text { not assumed }\end{array}$ & & & 0.318 & 28.58 & 0.753 & 0.111 & 0.34986 \\
\hline $\begin{array}{l}\text { Publishers } \\
\text { Aids-Under- }\end{array}$ & $\begin{array}{l}\text { Equal variances } \\
\text { assumed }\end{array}$ & 2.506 & 0.125 & 0.257 & 28.00 & 0.799 & 0.107 & 0.41620 \\
\hline Level & $\begin{array}{l}\text { Equal variances } \\
\text { not assumed }\end{array}$ & & & 0.253 & 24.56 & 0.802 & 0.107 & 0.42316 \\
\hline $\begin{array}{l}\text { Laser } \\
\text { Pointer- }\end{array}$ & $\begin{array}{l}\text { Equal variances } \\
\text { assumed }\end{array}$ & 0.284 & 0.598 & 0.182 & 31.00 & 0.857 & 0.056 & 0.30511 \\
\hline Grad-Level & $\begin{array}{l}\text { Equal variances } \\
\text { not assumed }\end{array}$ & & & 0.184 & 30.84 & 0.855 & 0.056 & 0.30183 \\
\hline $\begin{array}{l}\text { Laser } \\
\text { Pointer- }\end{array}$ & $\begin{array}{l}\text { Equal variances } \\
\text { assumed }\end{array}$ & 1.199 & 0.282 & 0.535 & 29.00 & 0.597 & 0.171 & 0.31917 \\
\hline Under-Level & $\begin{array}{l}\text { Equal variances } \\
\text { not assumed }\end{array}$ & & & 0.539 & 28.59 & 0.594 & 0.171 & 0.31719 \\
\hline $\begin{array}{l}\text { Laptop- } \\
\text { Grad-Level }\end{array}$ & $\begin{array}{l}\text { Equal variances } \\
\text { assumed }\end{array}$ & 1.824 & 0.187 & -0.939 & 30.00 & 0.355 & -0.381 & 0.40555 \\
\hline & $\begin{array}{l}\text { Equal variances } \\
\text { not assumed }\end{array}$ & & & -0.918 & 25.22 & 0.367 & -0.381 & 0.41510 \\
\hline $\begin{array}{l}\text { Laptop- } \\
\text { Under-Level }\end{array}$ & $\begin{array}{l}\text { Equal variances } \\
\text { assumed }\end{array}$ & 0.716 & 0.404 & -0.023 & 29.00 & 0.982 & -0.008 & 0.36943 \\
\hline & $\begin{array}{l}\text { Equal variances } \\
\text { not assumed }\end{array}$ & & & -0.023 & 26.87 & 0.982 & -0.008 & 0.37246 \\
\hline $\begin{array}{l}\text { Elmo } \\
\text { Projector- }\end{array}$ & $\begin{array}{l}\text { Equal variances } \\
\text { assumed }\end{array}$ & 0.609 & 0.441 & -1.278 & 30.00 & 0.211 & -0.524 & 0.41000 \\
\hline Grad-Level & $\begin{array}{l}\text { Equal variances } \\
\text { not assumed }\end{array}$ & & & -1.261 & 26.56 & 0.218 & -0.524 & 0.41541 \\
\hline $\begin{array}{l}\text { Elmo } \\
\text { Projector- }\end{array}$ & $\begin{array}{l}\text { Equal variances } \\
\text { assumed }\end{array}$ & 0.040 & 0.843 & 0.302 & 28.00 & 0.765 & 0.116 & 0.38424 \\
\hline Under-Level & $\begin{array}{l}\text { Equal variances } \\
\text { not assumed }\end{array}$ & & & 0.303 & 27.82 & 0.764 & 0.116 & 0.38267 \\
\hline $\begin{array}{l}\text { Infocus } \\
\text { Projector- }\end{array}$ & $\begin{array}{l}\text { Equal variances } \\
\text { assumed }\end{array}$ & 1.904 & 0.178 & 1.864 & 30.00 & 0.072 & 0.778 & 0.41715 \\
\hline Grad-Level & $\begin{array}{l}\text { Equal variances } \\
\text { not assumed }\end{array}$ & & & 1.893 & 29.40 & 0.068 & 0.778 & 0.41093 \\
\hline $\begin{array}{l}\text { Infocus } \\
\text { Projector- }\end{array}$ & $\begin{array}{l}\text { Equal variances } \\
\text { assumed }\end{array}$ & 6.894 & 0.015 & 2.210 & 25.00 & 0.036 & 1.074 & 0.48595 \\
\hline Under-Level & $\begin{array}{l}\text { Equal variances } \\
\text { not assumed }\end{array}$ & & & 2.387 & 24.97 & 0.025 & 1.074 & 0.44992 \\
\hline
\end{tabular}

Table 6 illustrates the findings with respect to the comparison between part and full-time faculty regarding the value of use of the various hard technologies at both the undergraduate and graduate levels. Only the perceived value of the Infocus projector at the undergraduate level was significant ( $\mathrm{p} .044)$ and that was only under the assumption of equal variances. None of the rest of the mean responses to the items in the inventory of hard technologies at either the graduate or undergraduate levels could be distinguished statistically between the two faculty groups. Tables 7 and 8 depict the results of the comparisons of means of levels of use (Table 7) and value of use (Table 8) of classroom types. There were no significant differences between the part-time and full-time faculty on either the level or value of use at either the undergraduate or graduate level with respect to the three classroom types.

\section{Research Question 5}

We ran a univariate ANOVA on each item found to be significant in the $t$ tests in order to investigate whether or not the factors "teaching experience" or "department" may explain some of the difference. Neither factor was significant in any of the ANOVAs. We also ran ANOVAs on each soft technology value judgment at both the undergraduate and graduate levels. Consistent with our prior research on full-time faculty, neither teaching experience nor departmental affiliation was found to be significant in any of the ANOVAs. 
Table 6

Full vs. Part-Time Faculty, Hard Technologies - Value of Use, Independent Samples Test

\begin{tabular}{|c|c|c|c|c|c|c|c|c|}
\hline & \multicolumn{2}{|c|}{$\begin{array}{c}\text { Levene's Test for } \\
\text { Equality of } \\
\text { Variances }\end{array}$} & \multicolumn{5}{|c|}{ t-test for Equality of Means } \\
\hline & & $\mathbf{F}$ & Sig. & $\mathbf{t}$ & df & $\underset{\text { (2-tail) }}{\text { Sig. }}$ & $\begin{array}{c}\text { Mean } \\
\text { Difference }\end{array}$ & $\begin{array}{l}\text { Std. Error } \\
\text { Difference }\end{array}$ \\
\hline $\begin{array}{l}\text { OH Proj.- } \\
\text { Grad-Value }\end{array}$ & $\begin{array}{l}\text { Equal variances } \\
\text { assumed } \\
\text { Equal variances } \\
\text { not assumed }\end{array}$ & 0.025 & 0.875 & $\begin{array}{l}0.750 \\
0.750\end{array}$ & $\begin{array}{l}28.00 \\
27.94\end{array}$ & $\begin{array}{l}0.459 \\
0.459\end{array}$ & $\begin{array}{l}0.333 \\
0.333\end{array}$ & $\begin{array}{l}0.444 \\
0.444\end{array}$ \\
\hline $\begin{array}{l}\text { OH Proj.- } \\
\text { Under-Value }\end{array}$ & $\begin{array}{l}\text { Equal variances } \\
\text { assumed } \\
\text { Equal variances } \\
\text { not assumed }\end{array}$ & 0.003 & 0.954 & $\begin{array}{l}0.074 \\
0.073\end{array}$ & $\begin{array}{l}24.00 \\
22.69\end{array}$ & $\begin{array}{l}0.942 \\
0.942\end{array}$ & $\begin{array}{l}0.036 \\
0.036\end{array}$ & $\begin{array}{l}0.486 \\
0.489\end{array}$ \\
\hline $\begin{array}{l}\text { E-Mail-Grad- } \\
\text { Value }\end{array}$ & $\begin{array}{l}\text { Equal variances } \\
\text { assumed } \\
\text { Equal variances } \\
\text { not assumed }\end{array}$ & 0.643 & 0.429 & $\begin{array}{l}0.466 \\
0.462\end{array}$ & $\begin{array}{l}28.00 \\
26.31\end{array}$ & $\begin{array}{l}0.645 \\
0.648\end{array}$ & $\begin{array}{l}0.098 \\
0.098\end{array}$ & $\begin{array}{l}0.211 \\
0.213\end{array}$ \\
\hline $\begin{array}{l}\text { E-Mail- } \\
\text { Under-Value }\end{array}$ & $\begin{array}{l}\text { Equal variances } \\
\text { assumed } \\
\text { Equal variances } \\
\text { not assumed }\end{array}$ & 7.066 & 0.013 & $\begin{array}{l}1.832 \\
1.880\end{array}$ & $\begin{array}{l}28.00 \\
26.36\end{array}$ & $\begin{array}{l}0.078 \\
0.071\end{array}$ & $\begin{array}{l}0.527 \\
0.527\end{array}$ & $\begin{array}{l}0.288 \\
0.280\end{array}$ \\
\hline $\begin{array}{l}\text { Streaming } \\
\text { Video-Grad- } \\
\text { Value }\end{array}$ & $\begin{array}{l}\text { Equal variances } \\
\text { assumed } \\
\text { Equal variances } \\
\text { not assumed }\end{array}$ & 1.773 & 0.206 & $\begin{array}{l}0.393 \\
0.359\end{array}$ & $\begin{array}{l}13.00 \\
6.47\end{array}$ & $\begin{array}{l}0.700 \\
0.731\end{array}$ & $\begin{array}{l}0.200 \\
0.200\end{array}$ & $\begin{array}{l}0.508 \\
0.558\end{array}$ \\
\hline $\begin{array}{l}\text { Streaming } \\
\text { Video-Under- } \\
\text { Value }\end{array}$ & $\begin{array}{l}\text { Equal variances } \\
\text { assumed } \\
\text { Equal variances } \\
\text { not assumed }\end{array}$ & 4.631 & 0.054 & $\begin{array}{l}1.792 \\
1.565\end{array}$ & $\begin{array}{l}11.00 \\
5.57\end{array}$ & $\begin{array}{l}0.101 \\
0.173\end{array}$ & $\begin{array}{l}1.025 \\
1.025\end{array}$ & $\begin{array}{l}0.572 \\
0.655\end{array}$ \\
\hline $\begin{array}{l}\text { Internet } \\
\text { Access-Grad- } \\
\text { Value }\end{array}$ & $\begin{array}{l}\text { Equal variances } \\
\text { assumed } \\
\text { Equal variances } \\
\text { not assumed }\end{array}$ & 2.163 & 0.155 & $\begin{array}{l}-0.682 \\
-0.729\end{array}$ & $\begin{array}{l}22.00 \\
21.94\end{array}$ & $\begin{array}{l}0.502 \\
0.474\end{array}$ & $\begin{array}{l}-0.157 \\
-0.157\end{array}$ & $\begin{array}{l}0.230 \\
0.215\end{array}$ \\
\hline $\begin{array}{l}\text { Internet } \\
\text { Access- } \\
\text { Under-Value }\end{array}$ & $\begin{array}{l}\text { Equal variances } \\
\text { assumed } \\
\text { Equal variances } \\
\text { not assumed }\end{array}$ & 8.107 & 0.011 & $\begin{array}{l}1.124 \\
1.049\end{array}$ & $\begin{array}{l}18.00 \\
10.77\end{array}$ & $\begin{array}{l}0.276 \\
0.317\end{array}$ & $\begin{array}{l}0.414 \\
0.414\end{array}$ & $\begin{array}{l}0.369 \\
0.395\end{array}$ \\
\hline $\begin{array}{l}\text { BlackBoard- } \\
\text { Grad-Value }\end{array}$ & $\begin{array}{l}\text { Equal variances } \\
\text { assumed } \\
\text { Equal variances } \\
\text { not assumed }\end{array}$ & 0.531 & 0.475 & $\begin{array}{l}0.795 \\
0.785\end{array}$ & $\begin{array}{l}20.00 \\
18.14\end{array}$ & $\begin{array}{l}0.436 \\
0.443\end{array}$ & $\begin{array}{l}0.350 \\
0.350\end{array}$ & $\begin{array}{l}0.440 \\
0.446\end{array}$ \\
\hline $\begin{array}{l}\text { BlackBoard- } \\
\text { Under-Value }\end{array}$ & $\begin{array}{l}\text { Equal variances } \\
\text { assumed } \\
\text { Equal variances } \\
\text { not assumed }\end{array}$ & 5.163 & 0.038 & $\begin{array}{l}1.617 \\
1.582\end{array}$ & $\begin{array}{l}15.00 \\
12.39\end{array}$ & $\begin{array}{l}0.127 \\
0.139\end{array}$ & $\begin{array}{l}0.694 \\
0.694\end{array}$ & $\begin{array}{l}0.430 \\
0.439\end{array}$ \\
\hline $\begin{array}{l}\text { PowerPoint- } \\
\text { Grad-Value }\end{array}$ & $\begin{array}{l}\text { Equal variances } \\
\text { assumed } \\
\text { Equal variances } \\
\text { not assumed }\end{array}$ & 2.167 & 0.153 & $\begin{array}{l}0.000 \\
0.000\end{array}$ & $\begin{array}{l}26.00 \\
22.96\end{array}$ & $\begin{array}{l}1.000 \\
1.000\end{array}$ & $\begin{array}{l}0.000 \\
0.000\end{array}$ & $\begin{array}{l}0.246 \\
0.246\end{array}$ \\
\hline $\begin{array}{l}\text { PowerPoint- } \\
\text { Under-Value }\end{array}$ & $\begin{array}{l}\text { Equal variances } \\
\text { assumed } \\
\text { Equal variances } \\
\text { not assumed }\end{array}$ & 0.848 & 0.367 & $\begin{array}{l}0.278 \\
0.273\end{array}$ & $\begin{array}{l}22.00 \\
19.17\end{array}$ & $\begin{array}{l}0.784 \\
0.788\end{array}$ & $\begin{array}{l}0.084 \\
0.084\end{array}$ & $\begin{array}{l}0.302 \\
0.308\end{array}$ \\
\hline $\begin{array}{l}\text { Publishers } \\
\text { Aids-Grad- } \\
\text { Value }\end{array}$ & $\begin{array}{l}\text { Equal variances } \\
\text { assumed } \\
\text { Equal variances } \\
\text { not assumed }\end{array}$ & 0.094 & 0.761 & $\begin{array}{l}-0.292 \\
-0.293\end{array}$ & $\begin{array}{l}27.00 \\
26.17\end{array}$ & $\begin{array}{l}0.772 \\
0.772\end{array}$ & $\begin{array}{l}-0.087 \\
-0.087\end{array}$ & $\begin{array}{l}0.296 \\
0.295\end{array}$ \\
\hline
\end{tabular}




\begin{tabular}{|c|c|c|c|c|c|c|c|c|}
\hline \multirow{2}{*}{$\begin{array}{l}\text { Publishers } \\
\text { Aids-Under- } \\
\text { Value }\end{array}$} & $\begin{array}{l}\text { Equal variances } \\
\text { assumed }\end{array}$ & \multirow[t]{2}{*}{1.926} & \multirow[t]{2}{*}{0.179} & 0.866 & 23.00 & 0.396 & 0.318 & 0.368 \\
\hline & $\begin{array}{l}\text { Equal variances } \\
\text { not assumed }\end{array}$ & & & 0.830 & 17.29 & 0.418 & 0.318 & 0.383 \\
\hline \multirow[t]{2}{*}{$\begin{array}{l}\text { Laser Pointer- } \\
\text { Grad-Value }\end{array}$} & $\begin{array}{l}\text { Equal variances } \\
\text { assumed }\end{array}$ & \multirow[t]{2}{*}{1.477} & \multirow[t]{2}{*}{0.250} & 0.718 & 11.00 & 0.487 & 0.525 & 0.731 \\
\hline & $\begin{array}{l}\text { Equal variances } \\
\text { not assumed }\end{array}$ & & & 0.668 & 6.77 & 0.526 & 0.525 & 0.786 \\
\hline \multirow[t]{2}{*}{$\begin{array}{l}\text { Laser Pointer- } \\
\text { Under-Value }\end{array}$} & $\begin{array}{l}\text { Equal variances } \\
\text { assumed }\end{array}$ & \multirow[t]{2}{*}{0.405} & \multirow[t]{2}{*}{0.545} & 0.405 & 7.00 & 0.698 & 0.400 & 0.989 \\
\hline & $\begin{array}{l}\text { Equal variances } \\
\text { not assumed }\end{array}$ & & & 0.408 & 6.76 & 0.696 & 0.400 & 0.980 \\
\hline \multirow[t]{2}{*}{$\begin{array}{l}\text { Laptop-Grad- } \\
\text { Value }\end{array}$} & $\begin{array}{l}\text { Equal variances } \\
\text { assumed }\end{array}$ & \multirow[t]{2}{*}{0.339} & \multirow[t]{2}{*}{0.568} & 0.927 & 17.00 & 0.367 & 0.344 & 0.372 \\
\hline & $\begin{array}{l}\text { Equal variances } \\
\text { not assumed }\end{array}$ & & & 0.936 & 16.91 & 0.362 & 0.344 & 0.368 \\
\hline \multirow[t]{2}{*}{$\begin{array}{l}\text { Laptop- } \\
\text { Under-Value }\end{array}$} & $\begin{array}{l}\text { Equal variances } \\
\text { assumed }\end{array}$ & \multirow[t]{2}{*}{1.360} & \multirow[t]{2}{*}{0.265} & 1.619 & 13.00 & 0.129 & 0.786 & 0.485 \\
\hline & $\begin{array}{l}\text { Equal variances } \\
\text { not assumed }\end{array}$ & & & 1.577 & 10.37 & 0.145 & 0.786 & 0.498 \\
\hline \multirow{2}{*}{$\begin{array}{l}\text { Elmo } \\
\text { Projector- } \\
\text { Grad-Value }\end{array}$} & $\begin{array}{l}\text { Equal variances } \\
\text { assumed }\end{array}$ & \multirow[t]{2}{*}{1.164} & \multirow[t]{2}{*}{0.297} & 0.248 & 16.00 & 0.807 & 0.111 & 0.448 \\
\hline & $\begin{array}{l}\text { Equal variances } \\
\text { not assumed }\end{array}$ & & & 0.248 & 14.49 & 0.808 & 0.111 & 0.448 \\
\hline \multirow{2}{*}{$\begin{array}{l}\text { Elmo } \\
\text { Projector- } \\
\text { Under-Value }\end{array}$} & $\begin{array}{l}\text { Equal variances } \\
\text { assumed }\end{array}$ & \multirow[t]{2}{*}{1.378} & \multirow[t]{2}{*}{0.271} & 1.116 & 9.00 & 0.293 & 0.679 & 0.608 \\
\hline & $\begin{array}{l}\text { Equal variances } \\
\text { not assumed }\end{array}$ & & & 1.368 & 8.75 & 0.206 & 0.679 & 0.496 \\
\hline \multirow{2}{*}{$\begin{array}{l}\text { Infocus } \\
\text { Projector- } \\
\text { Grad-Value }\end{array}$} & $\begin{array}{l}\text { Equal variances } \\
\text { assumed }\end{array}$ & \multirow[t]{2}{*}{6.297} & \multirow[t]{2}{*}{0.025} & 1.643 & 14.00 & 0.123 & 0.945 & 0.575 \\
\hline & $\begin{array}{l}\text { Equal variances } \\
\text { not assumed }\end{array}$ & & & 1.310 & 5.10 & 0.246 & 0.945 & 0.722 \\
\hline \multirow{2}{*}{$\begin{array}{l}\text { Infocus } \\
\text { Projector- } \\
\text { Under-Value }\end{array}$} & $\begin{array}{l}\text { Equal variances } \\
\text { assumed }\end{array}$ & \multirow[t]{2}{*}{0.623} & \multirow[t]{2}{*}{0.446} & 2.280 & 11.00 & 0.044 & 1.444 & 0.633 \\
\hline & $\begin{array}{l}\text { Equal variances } \\
\text { not assumed }\end{array}$ & & & 1.886 & 4.08 & 0.131 & 1.444 & 0.766 \\
\hline
\end{tabular}

\section{DISCUSSION, FUTURE RESEARCH, AND LIMITATIONS}

We found a very high level of consensus between the full-time and part-time faculty groups at this business school. We did find some differences. Part-time faculty valued and used attendance significantly more than did fulltime faculty. Part-time faculty placed significantly less value on team work at the graduate level than did full-time faculty. Lastly, and we think of peripheral importance, part-time faculty valued and used Infocus projectors less than full-time faculty members. However, the overall message is that, in the environment studied, part-time and full-time faculty shared remarkably similar traits concerning both the level of use and the perceived value of use of a wide range of pedagogical tools, approaches, and settings.

As we discussed and analyzed in our previous paper, the instrument also supports the comparison of "value of use" vs. "level of use" as an indicator of institutional, physical, or motivational constraints on high use levels of various technologies or settings. Given the high level of similarity between the two groups of faculty, a similar analysis here would have been redundant. However, in other settings where part-time faculty measures differ significantly from those of full-time faculty, such an analysis would be of interest.

The growth of part-time faculty as a percentage of total faculty is a matter of concern to everyone involved in higher education. The existing literature indicates that these concerns may have many dimensions. Among those dimensions are budget issues, graduation rates, grade inflation, level of student contact, and social justice issues. Of 
particular interest to schools of business are the new AACSB standards that clearly direct every school's attention to the issues involving the level of "non-participating" faculty members, their qualifications, and their integration into the institutional teaching mission. We have extended the area of concern by focusing in this paper on pedagogical issues involving the attitudes toward the level of use and value of use of a wide range of approaches, tools, and settings affecting the teaching mission. We believe that this introductory research can help schools identify areas needing attention and development, and can help identify gaps between full and part-time faculty.

Table 7

Full vs. Part-Time Faculty, Classroom Types - Level of Use, Independent Samples Test

\begin{tabular}{|c|c|c|c|c|c|c|c|c|}
\hline & & $\begin{array}{r}\text { Leven } \\
\text { Eq } \\
\mathbf{V a} \\
\end{array}$ & $\begin{array}{l}\text { est for } \\
\text { of } \\
\text { ces }\end{array}$ & & t-te & r Equali & of Means & \\
\hline & & $\mathbf{F}$ & Sig. & $\mathbf{t}$ & df & $\underset{\text { (2-tail) }}{\text { Sig. }}$ & $\begin{array}{c}\text { Mean } \\
\text { Difference }\end{array}$ & $\begin{array}{l}\text { Std. Error } \\
\text { Difference }\end{array}$ \\
\hline $\begin{array}{l}\text { Smart Class.- } \\
\text { Grad-Level }\end{array}$ & $\begin{array}{l}\text { Equal variances } \\
\text { assumed } \\
\text { Equal variances } \\
\text { not assumed }\end{array}$ & 0.046 & 0.832 & $\begin{array}{l}-0.250 \\
-0.250\end{array}$ & $\begin{array}{l}31.00 \\
30.02\end{array}$ & $\begin{array}{l}0.805 \\
0.804\end{array}$ & $\begin{array}{l}-0.089 \\
-0.089\end{array}$ & $\begin{array}{l}0.356 \\
0.356\end{array}$ \\
\hline $\begin{array}{l}\text { Smart Class.- } \\
\text { Under-Level }\end{array}$ & $\begin{array}{l}\text { Equal variances } \\
\text { assumed } \\
\text { Equal variances } \\
\text { not assumed }\end{array}$ & 0.959 & 0.336 & $\begin{array}{l}1.101 \\
1.121\end{array}$ & $\begin{array}{l}27.00 \\
26.93\end{array}$ & $\begin{array}{l}0.280 \\
0.272\end{array}$ & $\begin{array}{l}0.476 \\
0.476\end{array}$ & $\begin{array}{l}0.432 \\
0.425\end{array}$ \\
\hline $\begin{array}{l}\text { Hybrid Class.- } \\
\text { Grad-Level }\end{array}$ & $\begin{array}{l}\text { Equal variances } \\
\text { assumed } \\
\text { Equal variances } \\
\text { not assumed }\end{array}$ & 0.050 & 0.825 & $\begin{array}{l}-1.527 \\
-1.570\end{array}$ & $\begin{array}{l}28.00 \\
25.85\end{array}$ & $\begin{array}{l}0.138 \\
0.128\end{array}$ & $\begin{array}{l}-0.611 \\
-0.611\end{array}$ & $\begin{array}{l}0.400 \\
0.389\end{array}$ \\
\hline $\begin{array}{l}\text { Hybrid Class.- } \\
\text { Under-Level }\end{array}$ & $\begin{array}{l}\text { Equal variances } \\
\text { assumed } \\
\text { Equal variances } \\
\text { not assumed }\end{array}$ & 0.429 & 0.518 & $\begin{array}{l}-0.788 \\
-0.808\end{array}$ & $\begin{array}{l}26.00 \\
25.59\end{array}$ & $\begin{array}{l}0.438 \\
0.427\end{array}$ & $\begin{array}{l}-0.333 \\
-0.333\end{array}$ & $\begin{array}{l}0.423 \\
0.413\end{array}$ \\
\hline $\begin{array}{l}\text { Standard } \\
\text { Class.-Grad- } \\
\text { Level }\end{array}$ & $\begin{array}{l}\text { Equal variances } \\
\text { assumed } \\
\text { Equal variances } \\
\text { not assumed }\end{array}$ & 7.076 & 0.013 & $\begin{array}{l}1.303 \\
1.435\end{array}$ & $\begin{array}{l}28.00 \\
27.82\end{array}$ & $\begin{array}{l}0.203 \\
0.162\end{array}$ & $\begin{array}{l}0.500 \\
0.500\end{array}$ & $\begin{array}{l}0.384 \\
0.348\end{array}$ \\
\hline $\begin{array}{l}\text { Standard } \\
\text { Class.-Under- } \\
\text { Level }\end{array}$ & $\begin{array}{l}\text { Equal variances } \\
\text { assumed } \\
\text { Equal variances } \\
\text { not assumed }\end{array}$ & 4.527 & 0.043 & $\begin{array}{l}-0.384 \\
-0.397\end{array}$ & $\begin{array}{l}27.00 \\
26.67\end{array}$ & $\begin{array}{l}0.704 \\
0.695\end{array}$ & $\begin{array}{l}-0.159 \\
-0.159\end{array}$ & $\begin{array}{l}0.414 \\
0.400\end{array}$ \\
\hline
\end{tabular}

The next step in the research project is to study both the full time and adjunct populations in a different setting. We have identified a similar university that differs primarily in policies concerning the use of technology and the extent of availability of a range of technologies. The comparison university is similar in size and organizational structure. After that, if feasible, we will extend the research to include a variety of institutions and control for size, structure, technology policy, and technology availability.

Similar to our previous paper, the research results are limited by the small sample and the delimitation to only one university. Also, the part-time sample yielded smaller responses than the sample size on many questions because many part-time faculty members only teach classes at either the graduate or the undergraduate levels but not both. We also note that, although the research protected the privacy of the participants, part-time faculty may be more susceptible to considerations of job tenure and this could bias the results obtained. 
Table 8

Full vs. Part-Time Faculty, Classroom Types - Value of Use, Independent Samples Test

\begin{tabular}{|c|c|c|c|c|c|c|c|c|}
\hline & \multicolumn{2}{|c|}{$\begin{array}{c}\text { Levene's Test for } \\
\text { Equality of } \\
\text { Variances } \\
\end{array}$} & \multicolumn{5}{|c|}{ t-test for Equality of Means } \\
\hline & & $\mathbf{F}$ & Sig. & $\mathbf{t}$ & df & $\begin{array}{c}\text { Sig. } \\
\text { (2-tail) }\end{array}$ & $\begin{array}{c}\text { Mean } \\
\text { Difference }\end{array}$ & $\begin{array}{l}\text { Std. Error } \\
\text { Difference }\end{array}$ \\
\hline $\begin{array}{l}\text { Smart } \\
\text { Classroom- }\end{array}$ & $\begin{array}{l}\text { Equal variances } \\
\text { assumed }\end{array}$ & 3.593 & 0.068 & -0.850 & 29.0 & 0.402 & -0.210 & 0.247 \\
\hline Grad-Value & $\begin{array}{l}\text { Equal variances } \\
\text { not assumed }\end{array}$ & & & -0.912 & 22.4 & 0.372 & -0.210 & 0.230 \\
\hline $\begin{array}{l}\text { Smart } \\
\text { Classroom- }\end{array}$ & $\begin{array}{l}\text { Equal variances } \\
\text { assumed }\end{array}$ & 1.805 & 0.192 & 1.669 & 23.0 & 0.109 & 0.623 & 0.374 \\
\hline Under-Value & $\begin{array}{l}\text { Equal variances } \\
\text { not assumed }\end{array}$ & & & 1.621 & 18.7 & 0.122 & 0.623 & 0.384 \\
\hline $\begin{array}{l}\text { Hybrid } \\
\text { Classroom- }\end{array}$ & $\begin{array}{l}\text { Equal variances } \\
\text { assumed }\end{array}$ & 0.744 & 0.401 & 0.295 & 16.0 & 0.772 & 0.111 & 0.377 \\
\hline Grad-Value & $\begin{array}{l}\text { Equal variances } \\
\text { not assumed }\end{array}$ & & & 0.295 & 15.3 & 0.772 & 0.111 & 0.377 \\
\hline $\begin{array}{l}\text { Hybrid } \\
\text { Classroom- }\end{array}$ & $\begin{array}{l}\text { Equal variances } \\
\text { assumed }\end{array}$ & 0.883 & 0.361 & 0.976 & 16.0 & 0.343 & 0.425 & 0.435 \\
\hline Under-Value & $\begin{array}{l}\text { Equal variances } \\
\text { not assumed }\end{array}$ & & & 1.013 & 15.9 & 0.326 & 0.425 & 0.419 \\
\hline $\begin{array}{l}\text { Standard } \\
\text { Classroom- }\end{array}$ & $\begin{array}{l}\text { Equal variances } \\
\text { assumed }\end{array}$ & 0.684 & 0.416 & 1.448 & 26.0 & 0.159 & 0.583 & 0.403 \\
\hline Grad-Value & $\begin{array}{l}\text { Equal variances } \\
\text { not assumed }\end{array}$ & & & 1.469 & 25.0 & 0.154 & 0.583 & 0.397 \\
\hline $\begin{array}{l}\text { Standard } \\
\text { Classroom- }\end{array}$ & $\begin{array}{l}\text { Equal variances } \\
\text { assumed }\end{array}$ & 0.286 & 0.597 & -0.378 & 24.0 & 0.709 & -0.167 & 0.441 \\
\hline Under-Value & $\begin{array}{l}\text { Equal variances } \\
\text { not assumed }\end{array}$ & & & -0.380 & 23.8 & 0.707 & -0.167 & 0.438 \\
\hline
\end{tabular}

\section{ACKNOWLEDGEMENTS}

The authors would like to express their appreciation to Dean Anthony F. Libertella for his unwavering research support and to Dr. Allan Ashley, Chair of the Marketing Management, and Decision Sciences Department for his support and counsel during the research. Appreciation is also extended to Ms. Asita Mamlatdarna, Graduate Assistant, who provided excellent technical support.

\section{REFERENCES}

1. AACSB International, Eligibility Procedures and Accreditation Standards for Business Accreditation, Tampa, Florida, Revised: January 01, 2005, p.35-37.

2. Bianco-Mathis, Virginia and Chalofsky, eds., The Adjunct Faculty Handbook, Sage Publication, 1996, p.55.

3. Bowen, Howard R. and Schuster, Jack H., American Professors: A National Resource Imperiled; Oxford University Press, 1986, p.60-66.

4. Carroll, Jill, Do Adjuncts Have Time for Students? Chronicle of Higher Education; 7/25/2003, Vol. 49 Issue 46, P.C 4.

5. Chronicle of Higher Education Speaker says Adjuncts May Harm Students, November 18, 2005, p.13.

6. Conley, Valerie Martin and Leslie, David W., Part-time Instructional faculty and Staff: Who They Are, What they do and What they think, NCES 2002-163, p.8.

7. Ehrenberg, Ronald G., The Changing Nature of the Faculty Employment Practices Revised Draft, November 6, 2005, Presented at the TIAA-CREF Institute Conference on The New Balancing Act in Higher Education, NY, November 3-5, 2005. Retrieved from www.TIAA-CREFInstitute.org on 11/21/05. 
8. Forrest, Cataldi E., Fahimi, M., and Bradburn, E. M. (2005). 2004 National Study of Postsecondary Faculty (NSOPF: 04) Report on Faculty and Instructional Staff in Fall 2003 (NCES 2005-172). U.S. Department of Education. Washington, DC: National Center for Education Statistics. Retrieved from http://nces.ed.gov/pubsearch.

9. Fulton, Richard D., The Plight of Part-timers in Higher Education. Change; May/ June 2000, Vol. 32, Issue 3, p.6. As retrieved from Adelphi online resources.

10. Grappa, Judith M., Part-time Faculty: Higher Education at a Crossroads; Association for the Study of Higher Education, Report 3; 1984, p.4.

11. Grieve, Donald and Warden, Catherine, eds., Handbook II-Advanced Teaching Strategies for Adjunct Faculty.

12. http://www.4faculty.org (version4) accessed on 10/19/05.

13. http://www.AdjunctNation.com/ accessed on 11/26/05.

14. http://www.Adjunctopia.com/ accessed on 11/26/05.

15. Knight, Mark 4faculty.org- An Innovative Approach to Faculty Development Community College Journal of Research and Practice; Jan 2004, Vol. 28, Issue 1, p55-56. As retrieved online from Adelphi.edu/servlLet/WeBACC?Action=Item.

16. Lyons, Richard E., et al, Adjunct Professor's Guide to Success, The Surviving and Thriving in the College Classroom.

17. National Education Association Part-time and Temporary Faculty, 1989, p.1-3.

18. Payette, Dennis L., Enhanced Multi-faceted Teaching Methods, Journal of College Teaching and Learning, Vol. 1, No. 6, June 2004.

19. Payette, Dennis L. and Verreault, Daniel, Enhanced Multi-faceted Teaching Methods Phase II, Journal of College Teaching and learning, Vol. 2. No. 6, June 2005. p. 31-45.

20. Schroeder, Sandra, It's Time to give Adjuncts a Break, Chronicle of higher Education, October 28, 2005, p. B 27.

21. Sonner, Brenda S. A Is for Adjunct Examining Grade Inflation in Higher Education, Journal of Education for Business; Sept/Oct 2000, Vol. 76 Issue 1, p.5 as retrieved online through Adelphi.edu/servlLet/WeBACC?Action=Item.

22. Taylor, Vernon, Teaching Tips for Part-time teachers.

23. U.S. Department of Education, National center for Education Statistics (2002). A profile of Part-time Faculty: Fall 1998, NCES 2002-08, by Andrea Berger, Rita Kirshstein, Yu Zhang, and Kevin Carter, American Institute for Research, Linda J. Zimbler, Project Officer. Washington, DC: 2002. Accessed 11/26/05 from http://nces.ed.gov/pubsearch.

24. U.S. Department of Education. National Center for Education Statistics. E.D. TABS: Fall Staff in Postsecondary Institutions, 1995, NCES 98-228, by Stephen Roey and Rebecca Rak. Project Officers, Rosa Fernandez and Sam Barbett. Washington, D.C.: 1998, p.1-2. Accessed 11/26/05 from http://nces.ed.gov/pubsearch.

25. Wickun, William G. and Rock, Stanley E., The Role of Adjunct Faculty in Higher Education The Montana Professor Academic Journal; http://MTPRof.MSUN.edu/Win2000/Wickun.html. Accessed on 11/26/05. 